\title{
The Moderating Effect of Top Management Team's Power on the Relationship between CPA Independence \& Audit Quality
}

\author{
Ching Yen Li, Chao Sheng Liu, Faradillah Amalia Rivai
}

\begin{abstract}
This research integrates the top management teams (TMT)power theory, CPA economic independence theory, and reputation maintenance theory to explore the impact on audit quality. This study used the sample of firms listed on the Taiwan Stock Exchange (TSE) and Taipei Exchange (TPEx) from 2009 to 2016. The empirical results show that as the TMT power of Taiwan companies increases, the audit quality is higher. It is different from the general research that the TMT will conduct earning management based on self-interested behavior. The inference is due to Taiwan's relatively high proportion of family companies. In the face of the trend of social responsibility and the requirements of regulatory agencies, the company's strategy of maintaining corporate image and successfully operating over to the next generation is presented with high audit quality. In addition, when CPAs face important clients, the CPA's economy depends on important customers is greater than the effect of reputation maintenance, the audit quality will be reduced. When the TMT power is greater, it will offset the CPA's economic independence effect and enhance the audit quality.
\end{abstract}

\section{Keywords - Audit Quality, CPA Independence, Power Theory}

\section{INTRODUCTION}

$\mathrm{T}$ his paper investigates the moderating effect of Top management team's power on the relationship between $\mathrm{CPA}$ independence and auditing quality. Investigating this issue can provide valuable insights into the effectiveness of top management team power and CPA independence towards audit quality.

This study refers to $M$ Van Essen, $J$ Otten and EJ Carberry [1] and MB Muttakin, A Khan and DG Mihret [2] to measure the power of high-level managers, using the dichotomy to calculate scores for the following four component variables. Our proxy for TMT power is OWN, CEODU, TEN, and FAMILY. OWN is defined as the shareholding ratio of senior managers, where the higher the shareholding ratio of

- Author name is currently pursuing doctoral degree program in Accounting department in National Yunlin University of Science and Technology, Taiwan, PH-0932646199. E-mail:D10625001@yuntech.edu.tw

- Co-Author name is currently pursuing doctoral degree program in Accounting department in National Yunlin University of Science and Technology, Taiwan, PH0932580351.E-mail: D10525004@yuntech.edu.tw

- Co-Author name is currently pursuing doctoral degree program in Accounting department in National Yunlin University of Science and Technology, Taiwan,, $\mathrm{PH}$ 0984335185.E-mail: D10725003@gemail.yuntech.edu.tw senior managers, the greater the power of senior managers. CEODU is defined as a CEO duality where it refers to the chairman concurrently serving as the general manager. When the CEO has a dual identity, it will have a higher influence on its major decisionmaking process. TEN is defined as tenure of senior manager. The longer the tenure of senior managers, the more they can influence board decisions [3, 4] and the last proxy is FAMILY where it defined as family senior managers. Relevant research points out that the controlling family has a large number of nondiversified equity, which can be used as the chairman of the board of directors through controlling equity, and then control the positions of senior managers. It is in the company's unique position [5-7]. The judgment of a family business in data is taken from the Taiwan Economic News (TEJ). Therefore, if it is a family business, it is judged as a family CEO, which is regarded as one of the sources of power for high-level managers. For CPA independence, we use an audit fee. Following JH Choi, JB Kim, X Liu and DA Simunic [8], the fees vary with the size and complexity of the 
client's structure. If a higher audit fee is charged to a single client, it means that the CPA may rely more on a single client, which may affect the CPA's independence because to protect their personal interests, the CPA may not be able to perform the audit work independently.

Using 6,463 firm-year observations of Taiwanese listed companies from 2009 to 2016, the result shows that as the TMT power of Taiwan companies increases, the audit quality is higher. It is different from the general research that the TMT will conduct earning management based on self-interested behavior. The inference is due to Taiwan's relatively high proportion of family companies. In the face of the trend of social responsibility and the requirements of regulatory agencies, the company's strategy of maintaining corporate image and successfully operating over to the next generation is presented with high audit quality. In addition, when CPAs face important clients, the CPA's economic will depends on important customers is greater than the effect of reputation maintenance, the audit quality will be reduced because the CPA's independence is impaired. When the TMT power is greater, it will offset the CPA's economic dependence effect and enhance the audit quality. Our findings showed different results from another previous research. General research found that the powerful TMT may have more incentive to manage earnings when they have longtenured than TMT that have short-tenure.

We also conduct an additional test that we would like to understand the impact of high-tech industry top management team power and the independence of CPA on audit quality. The reason to conduct this additional test is that Taiwan's high-tech electronics industry has excellent manufacturing technology. Half of the listed companies in Taiwan are from the hightech industry. Our result found that the power of the top management team is negatively correlated with audit quality, and the independence of CPAs is positively correlated with audit quality, which supports Hypotheses 1 and 2.

The remainder of the paper is organized as follows. Section 2 reviews the literature and develops the hypotheses. Section 3 describes the research design.
Section 4 presents the data and empirical results. Section 5 provides additional analysis, and Section 6 provides concluding remarks.

\section{LITERATURE REVIEW AND HYPOTHESES DEVELOPMENT}

\subsection{THE ASSOCIATION BETWEEN TMT POWER AND AUDIT QUALITY REVIEW STAGE}

This subsection proposes how TMT power affects audit quality. The following study from CP Egri and $S$ Herman [9] defines that Top Management's power is influencing the organization's members through its leadership. Depending on their cognition, emphasis on specific issues, or influence the priorities of organizational, operational decisions by discretionary decision making. In firms, top managers are allowed considerable discretion in determining the informativeness of disclosure. Thus, Powerful top managers can wield substantial influence over corporate decision-making through power embedded in the corporate hierarchy. Top management team members can gain power through several dimensions of power such as structural, ownership, expertise, and prestige [10]. A previous study from TJ Chemmanur and I Paeglis [11] indicates that a knowledgeable TMT has better management quality. A TMT with better management quality is more likely to select better projects (having a larger net present value for any given investment scale) and implement them more ably. After establishing their leadership from the power, TMT members are more concerned with their reputation. This argument supported by study conducted by A Ali and W Zhang [12], suggests that managers care a lot about the market's perception of their ability because it is associated with several longterm benefits such as higher future compensation, reappointments, and managerial autonomy. Furthermore, a powerful top management can influence the organization's members through its power including impacting a significant financial reporting decision: auditor selection in order to protect their reputation and improve the firm performance and decrease the manager's incentives to manipulate earnings by hiring big-4 auditors.

Independent auditors, with their ability and experience, from a big four audit firm, is believed to 
help deter managers' incentive to manipulate earnings. Based on ESS Alzoubi [13], Earning Management is significantly less among companies hiring a Big four audit firm than companies utilizing the service of a non-Big Four audit firm. In an agency conflict setting, insiders may want to hire high-quality auditors to signal higher quality financial reporting to obtain favorable contracting terms, such as cost of equity [14]. Thus, a powerful top management team would be more likely to hire big-4 auditors to lower information asymmetry, reduce financing costs, and increase audit quality.

Therefore, we expect that compared to companies that have less power of top management teams, companies that have high power over top management teams will experience higher audit quality (lower discretionary accrual).

H1: TMT Power is associated with increasing audit quality.

\subsection{THE ASSOCIATION BETWEEN AUDITOR INDEPENDENCE AND AUDIT QUALITY}

Following statements from the study conducted by YC Lin, Y-H Lu, F-C Lin and Y-C Lu [15] define that auditor independence consists of two components: independence in appearance and independence of mind. Independence in appearance is the result

of others' perceptions. Auditor's independence plays an important role in public trust toward the accounting profession and thus becomes the cornerstone of the accounting profession. To mitigate the concern of auditor independence, regulators and investors have expressed and taken action.

Based on the passage of the 2002 Sarbanes-Oxley (SOX) Act, auditors are prohibited from providing non-audit service to their clients, and audit partners must be rotated every five years. To improve the transparency of the audit report to the user, the Public Company Accounting Oversight Board (PCAOB) requires audit firms to disclose the names of each audit engagement partner as well as the names of other audit firms that participated in each audit. The requirements are effective for audit reports issued in 2017.
Auditors face significant reputational and legal damage if they misstate a client's financial results [16]. When auditors lose their independence, the audit quality would be impaired, eroding the public's trust in the accounting profession (Y.-S. Chang et al. 2019). Therefore, Auditor independence has a significant impact on audit quality. However, auditors could become financially dependent on particular clients, which is why the Securities and Exchange Commission (SEC) prohibits audit firms from providing some non-audit services.

In this study, we will use audit fees to proxy auditor independence. We assume that total audit fees will cause the auditor to impair the independence toward the important client because of economics depending on the client. The previous study [17, 18] hypothesizes that, at a more conceptual level, Auditors become financially dependent on the client caused by the size of total fees paid to them. Consequently, total fees would be a more relevant measure of the threat to auditor independence than the non-audit component of the total fees. This line of reasoning is consistent with the theoretical prediction in LE DeAngelo [19]that auditors may have incentives to compromise their independence for an economically important client. These studies suggest that auditors compromise independence or that independence is perceived to be compromised for economically important clients.

Therefore, we expect for our second hypothesis that the size of total audit fees will significantly impact the independence of the auditor and impair the audit quality.

$\mathrm{H} 2$ : Auditor independence is associated with impairing the audit quality.

\subsection{THE ASSOCIATION BETWEEN TMT POWER AND AUDITOR INDEPENDENCE ON AUDIT QUALITY}

Following the data from the 2017 Annual Meeting of the Taiwan Institute of Directors, based on the analysis of the total number of listed and OTC companies in Taiwan in 2016, there are 1,624 companies from family businesses. It means that approximately $63 \%$ of the total market value in 
Taiwan is from the family business. The number of family entrepreneurs accounted for the total number of entrepreneurs is about $70 \%$, and the sample family companies in this study account for about $62.47 \%$. To sum up, most of the company's equity in Taiwan is controlled by family members. According to [7], family business CEOs tend to protect their own reputation and continue the sustainable operation of the business and pass it on the next generation. Therefore, the chief executive may avoid short-term opportunism such as earnings management and opaque financial reporting [20].

H3: The association of Auditor Independence to impair the audit quality is weakened by TMT power.

\section{METHODS}

\subsection{SAMPLE SELECTION AND DATA}

We choose companies as the research object in TWSE and TPEx, and the sample period is from 2009 to 2016. Considering that there is no consistent definition of the titles of senior managers in Taiwan business practice, we refer to the classification of the company's management and management positions in the database of Taiwan Economic Journal (TEJ) and define senior managers as influencing the company's decision-making and their future development. The CEO, president, general manager and key managers with significant relevance conduct data screening, sorting and analysis.

The main data sources include the company's website, the company's annual report, public brochure and financial report of the public information observatory, and the financial module, audit quality and corporate governance module in the TEJ database. The sample selection process is shown in Panel A in Table 1 below. The original sample numbered 10,996. After deducting the missing values of the database variables and the extreme values of each variable, the final number of samples included in the empirical hypothesis test totaled 6,463 .

Panel B in Table 1 is the sample year and industry distribution. The table shows that the electronics industry has the largest number of samples, with 3,225 (approximately 49.90\%). In contrast, agricultural technology has the least number of samples, with only 11 (About 0.17\%), showing that the electronics industry is the core of Taiwan current economic development and Taiwan's main source of tax revenue. The least number of companies is the agricultural science and technology industry. In recent years, Taiwan has actively transformed traditional industrial agriculture into new Value Chain agriculture and hopes to become a global green gold industry.

Table 1

Sample selection and industrial distribution

\begin{tabular}{lr}
\hline Panel A : Sample selection & Total \\
\hline $\begin{array}{l}\text { Companies on TWSE or TPEx from } \\
\text { the TEJ database (2009 to 2016) }\end{array}$ & 10,996 \\
Less: & \\
Companies with missing variables & 3,830 \\
information & 703 \\
Outlier of each variable & 6,463 \\
\hline Final sample
\end{tabular}




\begin{tabular}{|c|c|c|c|c|c|c|c|c|c|c|c|}
\hline \multicolumn{12}{|c|}{ Panel B : Distribution of all Data industries } \\
\hline $\begin{array}{l}\text { Industries } \\
\text { Code }^{\mathrm{a}}\end{array}$ & $\begin{array}{l}\text { Industry } \\
\text { Classification }\end{array}$ & 2009 & 2010 & 2011 & 2012 & 2013 & 2014 & 2015 & 2016 & Total & $\%$ \\
\hline 1 & Cement & 3 & 4 & 3 & 3 & 5 & 4 & 5 & 7 & 34 & 0.53 \\
\hline 2 & Food & 7 & 11 & 14 & 13 & 15 & 15 & 17 & 19 & 111 & 1.72 \\
\hline 3 & Plastic & 11 & 15 & 19 & 19 & 16 & 15 & 17 & 19 & 131 & 2.03 \\
\hline 4 & Textile & 23 & 24 & 27 & 23 & 26 & 27 & 31 & 33 & 214 & 3.31 \\
\hline 5 & Electric Machinery & 27 & 31 & 31 & 40 & 38 & 41 & 45 & 49 & 302 & 4.67 \\
\hline 6 & Electrical \& Cable & 5 & 9 & 8 & 8 & 9 & 9 & 10 & 10 & 68 & 1.05 \\
\hline 7 & Chemical/Biomedical & 42 & 44 & 58 & 74 & 76 & 77 & 84 & 90 & 545 & 8.43 \\
\hline 8 & Glass/Ceramic & 3 & 2 & 4 & 4 & 5 & 5 & 4 & 4 & 31 & 0.48 \\
\hline 9 & Paper & 1 & 1 & 1 & 1 & 1 & 1 & 3 & 4 & 13 & 0.20 \\
\hline 10 & Ferrous & 20 & 19 & 26 & 26 & 25 & 24 & 26 & 26 & 192 & 2.97 \\
\hline 11 & Rubber & 11 & 15 & 19 & 19 & 16 & 15 & 17 & 19 & 131 & 2.03 \\
\hline 12 & Vehicle & 9 & 9 & 10 & 10 & 13 & 12 & 13 & 12 & 88 & 1.36 \\
\hline 13 & Electronic & 313 & 367 & 403 & 380 & 399 & 417 & 450 & 496 & 3,225 & 49.90 \\
\hline 14 & Construction & 32 & 35 & 39 & 39 & 37 & 48 & 46 & 50 & 326 & 5.04 \\
\hline 15 & Transportation & 11 & 14 & 17 & 16 & 18 & 19 & 19 & 19 & 133 & 2.06 \\
\hline 16 & Tourism & 10 & 12 & 13 & 13 & 13 & 15 & 21 & 18 & 115 & 1.78 \\
\hline 17 & Financial & 17 & 22 & 23 & 21 & 17 & 20 & 24 & 17 & 161 & 2.49 \\
\hline 18 & Consumers Goods & 11 & 11 & 15 & 16 & 17 & 19 & 19 & 18 & 126 & 1.95 \\
\hline 20 & Others & 31 & 27 & 34 & 40 & 48 & 51 & 49 & 61 & 341 & 5.28 \\
\hline 23 & Oil, Gas \& Electricity & 6 & 8 & 9 & 9 & 10 & 10 & 9 & 10 & 71 & 1.10 \\
\hline 32 & Cultural \& Creative & 3 & 3 & 8 & 9 & 11 & 9 & 13 & 14 & 70 & 1.08 \\
\hline \multirow{3}{*}{$\begin{array}{l}33 \\
34 \\
\end{array}$} & $\begin{array}{l}\text { Agricultural } \\
\text { Technology }\end{array}$ & 1 & 1 & 1 & 2 & 2 & 1 & 1 & 2 & 11 & 0.17 \\
\hline & e-commerce & 1 & 2 & 2 & 2 & 4 & 5 & 4 & 4 & 24 & 0.37 \\
\hline & Final sample & 598 & 686 & 784 & 787 & 821 & 859 & 927 & 1,001 & 6,463 & 100 \\
\hline
\end{tabular}

\subsection{THE OPERATIONAL DEFINITION OF VARIABLES}

\subsubsection{DEPENDENT VARIABLE: AUDIT QUALITY} $\left(\mathrm{DAC}_{i, t}\right)$

This research explores the influence of CPAs' independence and the Top Management Team's power on audit quality. Abnormal accruals are related to earnings management and reflect the degree to which the management authority manipulates accruals. When CPAs indulge the authority to engage in earnings management, profits and losses distort. This will cause the audit quality to be low, so audit quality uses abnormal accounting as the proxy variable. When discussing the factors of CPA independence in the literature, abnormal accounting is often used to judge the audit quality[21-26];, and estimated by the revised Jones model [26, 27], The specific measurement method is as follows:

$$
\begin{aligned}
T A C / A_{t-1}= & \alpha_{d} / A_{t-1}+\alpha_{1}(\triangle S A L E S-\triangle A R) / \\
& A_{t-1}+\alpha_{2} P P E / A_{t-1}+\varepsilon
\end{aligned}
$$

$T A C=$ Total Accrual is the difference between current surplus and cash flow from operating activities.

$A_{t-1}=$ Total assets at the beginning of the period.

$\triangle S A L E S=$ Change in net sales revenue.

$\triangle A R=$ Changes in accounts receivable.

$P P E=$ Gross real estate, plant, and equipment.

$\varepsilon=$ Error term of regression model $。$

The error term in the above regression model is the abnormal accruals to be counted for this study $\left(D A C_{i, t}\right)$

\subsubsection{INDEPENDENT VARIABLE:}

1. Top Management Power (TMTPOWER $\left.R_{i, t}\right)$ 
This study refers to M Van Essen, J Otten and EJ Carberry [1] and MB Muttakin, A Khan and DG Mihret [2] to measure the power of high-level managers, using the dichotomy to calculate scores for the following four component variables. Then, after calculating the ratio of the actual score of the company in a particular year to the highest achievable score (i.e., 4 points), the high-level management team power conversion score TMTPOWER is calculated as the basis for regression analysis:

(1) Shareholding ratio of senior managers $\left(O W N_{i, t}\right)$ : Major shareholders can nominate members of the board of directors, and more closely monitor the management's compensation plan, and influence the board's decision (Smith, 1996; Shleifer \& Vishny, 1997). Therefore, the higher the shareholding ratio of senior managers, the greater the power of senior managers. If the company's high-level managers' share ownership is higher than the average share ownership, set the dummy variable to 1 , otherwise, it is 0 .

$O W N_{i, t}=$ (total number of shares held by senior managers/total number of outstanding shares)*100\%

(2) CEO duality $\left(C E O D U_{i, t}\right)$ : Refers to the chairman concurrently serving as the general manager. When the CEO has a dual identity, it will have a higher influence on the company's major decision-making process. If the general manager of the company also holds the position of chairman of the board of directors, set the dummy variable to 1 , otherwise, it is 0 .

(3) Tenure of senior managers $\left(T E N_{i, t}\right)$ : The company's operating power comes from its professional knowledge, and to obtain the support and trust of directors and company members [10], it takes a long time to develop. The longer the tenure of senior managers, the more they can influence board decisions $[3,4]$. If the tenure of the Top management teams exceeds the average, set the dummy variable to 1 ; otherwise, it is 0 .

$T E N_{i, t}=$ Average number of years of tenure of top management
(4) Family senior managers (FAMILY $\left.Y_{i, t}\right)$ : Relevant research points out that the controlling family has a large number of non-diversified equity, which can be used as the chairman of the board of directors through controlling equity, and then control the positions of senior managers. It is in the company's unique position [5-7]. The judgment of a family business in Taiwan is taken from the Taiwan Economic News (TEJ). Therefore, if it is a family business, it is judged as a family CEO, which is regarded as one of the sources of power for high-level managers. If the CEO identity belongs to the family $\mathrm{CEO}$, set the dummy variable to 1 , otherwise it is 0 .

\section{CPA independence $\left(A I_{i, t}\right)$}

Related research found that public auditing does provide some views on the independence of CPAs. CPAs charge fees based on the number of hours they spend on clients. The fees vary with the size and complexity of the client's structure [8]. If a higher audit fee is charged to a single client, it means that the CPA may rely more on a single client, which may affect the CPA's independence because in order to protect their personal interests, the CPA may not be able to perform the audit work independently. If the statement does not provide accurate and fair opinions, wrong opinions will be given [28]. Therefore, the CPA's independence is measured by the proportion of the total audit fees paid by the client under investigation to the total public fees collected by the accounting firm from all listed companies Sex. The measurement variables are as follows:

$$
\mathrm{AI}_{i, t}=\mathrm{Fee}_{i, t} / \Sigma \mathrm{Fee}_{i, t}
$$

3. Control variables: In summing up the past literature, this study also includes other relevant variables that affect audit quality as control variables for the regression model, which are explained as follows:

(1) Enterprise size $\left(S I Z E_{i, t}\right)$ : Use the logarithm of the company's total assets to control the impact of company size on abnormal counts[25, 29].

$S I Z E_{i, t}=\log ($ average total assets $\mathrm{t})$ 
(2) Growth rate of sales $\left(G R O W_{i, t}\right)$ : Use the growth opportunity of sales to control the counting of current abnormalities.

$G R O W_{i, t}=\left(\mathrm{SALE}_{t}-\mathrm{SALE}_{t-1}\right) / \mathrm{SALE}_{t-1}$

(3) Return on assets $\left(R O A_{t-1}\right)$ : The return on assets in the previous period controls the impact of the previous company's performance on the current abnormal count [22].

$R O A_{t-1}=$ Net profit before tax $\mathrm{t}-1 /$ Total assets $\mathrm{t}-1$

(4) Debt ratio $\left(D E B T_{i, t}\right)$ : ML DeFond and J Jiambalvo [30]; AP Sweeney [26] research found that the debt ratio of a company is higher, and the probability of breach of contract is higher, and there are more incentives to make a profit. On the other hand, a company with a higher debt ratio is more likely to have financial difficulties. To win concessions from creditors or unions, it will reduce its earnings [31].

$D E B T_{i, t}=$ total liabilities ${ }_{i, t} /$ total $_{\text {assets }}, t$

(5)Going Concern $\left(G C_{i, t}\right)$ : If the company has major doubts about continuing to operate, and the CPA issues a reserved or amended unqualified opinion, the company tends to report larger abnormalities and should be counted [32]. If there are major doubts, set it to 1 , and set it to 0 for others.

(6) Big firms $\left(B I G N_{i, t}\right): 1$ if the Big Four accounting firms financially audit the company, 0 otherwise.

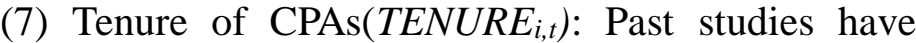
found that the length of the tenure of CPAs may affect audit quality.W Chi and $\mathrm{H}$ Huang [33] found that over-familiarity between CPAs and clients reduces audit quality. However, some evidence also shows that the longer the tenure, The lower the information asymmetry between CPAs and clients, the better the audit quality [22-24].

(8) Loss in the current period $\left(\operatorname{LOSS}_{i, t}\right)$ : The loss reported by the company in the current period is used to control the impact of current performance on the current abnormal accruals[21]. If the loss reported in the current period is 1 , otherwise, it is 0 .
(9) Current operating cash flow $\left(O F C_{i, t}\right)$ : control its negative relationship with the number of abnormal accruals in the current period [27] .

(10) Year (YEAR): annual control, setting dummy variables.

(11) Industry (INDUSTRY): Industry control, setting dummy variables.

\subsection{THE EMPIRICAL MODELS}

This study first established the following models (model 1, 2, and 3) to detect hypotheses H1, H2, and $\mathrm{H} 3$, respectively. The statistical estimation model of $\mathrm{H} 1$ in this study is established as follows:

$$
\begin{aligned}
\text { DAC }_{i, t}= & \alpha_{0}+\alpha_{1} \text { TMTPOWER }_{i, t}+\alpha_{2} \text { SIZE }_{i, t} \\
& +\alpha_{3} \text { GROW }_{i, t}+\alpha_{4} \text { ROA }_{i, t-1} \\
& +\alpha_{5} \text { DEBT }_{i, t}+\alpha_{6} \text { GC }_{i, t} \\
& +\alpha_{7} \text { BIGN }_{i, t}+\alpha_{8} \text { TENURE }_{i, t} \\
& +\alpha_{9} \text { LOSS }_{i, t}+\alpha_{10} \text { OFC }_{i, t} \\
& +\lambda Y E A R+\delta I N D U S T R Y+\varepsilon
\end{aligned}
$$

The statistical estimation mode of $\mathrm{H} 2$ is established below:

$$
\begin{aligned}
D A C_{i, t} & =\alpha_{0}+\alpha_{1} A_{i, t}+\alpha_{2} \text { SIZE }_{i, t} \\
& +\alpha_{3} \text { GROW }_{i, t}+\alpha_{4} \text { ROA }_{i, t} \\
& +\alpha_{5} \mathrm{DEBT}_{i, t}+\alpha_{6} G C_{i, t} \\
& +\alpha_{7} \mathrm{BIGN}_{i, t}+\alpha_{8} \operatorname{TENURE}_{i, t} \\
& +\alpha_{9} \mathrm{LOSS}_{i, t}+\alpha_{10} \mathrm{OFC}_{i, t} \\
& +\lambda Y E A R+\delta I N D U S T R Y+\varepsilon
\end{aligned}
$$

The statistical estimation mode of $\mathrm{H} 3$ is established below:

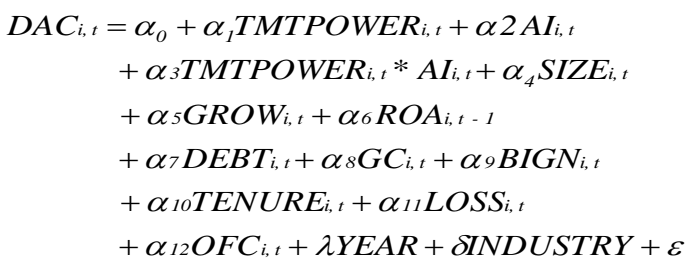




\section{EMPIRICAL RESULTS AND ANALYSIS}

\subsection{DESCRIPTIVE STATISTICS}

Table 2 is a narrative statistics table of the variables in this study. The powers of the Top management teams of Part A and Part B are 0.493 and 0.468 , respectively, and the CPA independence is 0.020 and 0.016, respectively. In terms of control variables, the reported losses in the current period were 0.216 and 0.141 , respectively, indicating that if the sample companies have reported losses in the current period, they may adjust their net losses upward to benefit their business results in the future; the debt ratios are 0.403 and 0.475 , respectively. The inference is that if the sample company has a relatively high debt ratio, to meet the conditions of the loan contract, the strategy of upward management of earnings is carried out to affect the quality of the audit.

Table 2 Descriptive statistics

Part A DAC $<0(n=5,339)$

\begin{tabular}{lcccc}
\hline Variable & Mean & Std.De. & Min & Max \\
\hline DAC & -0.015 & 0.008 & -0.086 & 0.000 \\
TMTPOWER & 0.493 & 0.273 & 0.000 & 1.000 \\
AI & 0.020 & 0.057 & 0.000 & 0.449 \\
SIZE & 14.974 & 1.211 & 11.119 & 20.580 \\
GROW & 0.098 & 1.264 & -2.640 & 56.036 \\
ROA & 0.083 & 0.086 & -0.211 & 0.376 \\
DEBT & 0.403 & 0.188 & 0.006 & 0.993 \\
GC & 0.005 & 0.071 & 0.000 & 1.000 \\
BIGC & 0.862 & 0.345 & 0.000 & 1.000 \\
TENURE & 4.279 & 1.822 & 1.000 & 18.000 \\
LOSS & 0.216 & 0.411 & 0.000 & 1.000 \\
OFC & 0.064 & 0.111 & -0.884 & 0.616 \\
\hline
\end{tabular}

Part B DAC $>0(\mathrm{n}=1,124)$

\begin{tabular}{lcccc}
\hline Variable & Mean & Std.Dev & Min & Max \\
\hline DAC & 0.055 & 0.081 & 0.000 & 0.369 \\
TMTPOWER & 0.468 & 0.261 & 0.000 & 1.000 \\
AI & 0.016 & 0.039 & 0.001 & 0.447 \\
SIZE & 17.186 & 1.132 & 14.665 & 20.525 \\
GROW & 0.090 & 0.692 & -0.875 & 17.230 \\
ROA & 0.102 & 0.074 & -0.203 & 0.372 \\
DEBT & 0.475 & 0.158 & 0.037 & 0.982 \\
GC & 0.002 & 0.042 & 0.000 & 1.000 \\
BIGC & 0.934 & 0.248 & 0.000 & 1.000 \\
TENURE & 4.368 & 1.722 & 1.000 & 10.000
\end{tabular}

\begin{tabular}{lllll} 
LOSS & 0.141 & 0.348 & 0.000 & 1.000 \\
OFC & 0.082 & 0.086 & -0.584 & 0.415 \\
\hline
\end{tabular}

\subsection{CORRELATION ANALYSIS}

The analysis of the correlation coefficients of various variables in Table 3 shows that the power of the Top management teams (TMTPOWER $R_{i, t}$ ) and the audit quality $\left(D A C_{i, t}\right)$ are significantly negatively correlated, which means that the more powerful the company of the Top management teams will not conduct earnings management. The lower the CPA's independence, the greater the company's earnings management space, and the relatively lower audit quality. In addition, this study conducted a multivariate collinearity analysis. The maximum variable VIF was 6.09 and all were less than 10 , indicating that there should be no multivariate severe collinearity Linear problem (un-tabulated). 
Table 3

Correlations among Testing Variables

\begin{tabular}{|c|c|c|c|c|c|c|c|c|c|c|c|c|}
\hline $\mathrm{N}=6,463$ & DAC & $\begin{array}{c}\text { TMT } \\
\text { POWE } \\
\text { R }\end{array}$ & AI & SIZE & GROW & ROA & DEBT & GC & BIGN & $\begin{array}{c}\text { TENU } \\
\text { RE }\end{array}$ & LOSS & OFC \\
\hline$\overline{\mathrm{DAC}}$ & 1.000 & $-0.032^{* *}$ & $0.240^{* * *}$ & $0.668^{* *}$ & $0.097^{* *}$ & 0.022 & $0.113^{* *}$ & $-0.028^{*}$ & $0.085^{* *}$ & $0.025^{*}$ & $-0.046^{* *}$ & -0.009 \\
\hline $\begin{array}{l}\text { TMTPOWE } \\
\text { R }\end{array}$ & $-0.032^{* *}$ & 1.000 & 0.009 & $-0.078^{* *}$ & $-0.048^{* *}$ & -0.007 & -0.006 & -0.010 & $-0.063^{* *}$ & 0.017 & 0.018 & -0.010 \\
\hline AI & $0.240^{* *}$ & 0.009 & 1.000 & $0.312^{* *}$ & $-0.028^{*}$ & $-0.027^{*}$ & $0.208^{* *}$ & $0.032^{* *}$ & $-0.571^{* *}$ & $-0.040^{* *}$ & -0.002 & $-0.038^{* *}$ \\
\hline SIZE & $0.668^{* *}$ & $-0.078^{* *}$ & $0.312^{* *}$ & 1.000 & $0.034^{* *}$ & $0.061^{* *}$ & $0.393^{* *}$ & $-0.059^{* *}$ & $0.081^{* *}$ & $0.036^{* *}$ & $-0.186^{* *}$ & 0.014 \\
\hline GROW & $0.097^{* *}$ & $-0.048^{* *}$ & $-0.028^{*}$ & $0.034^{* *}$ & 1.000 & $0.373^{* *}$ & $0.063^{* *}$ & $-0.070^{* *}$ & $0.045^{* *}$ & 0.008 & $-0.275^{* *}$ & $0.143^{* *}$ \\
\hline ROA & 0.022 & -0.007 & $-0.027^{*}$ & $0.061^{* *}$ & $0.373^{* *}$ & 1.000 & $-0.210^{* *}$ & $-0.073^{* *}$ & $0.108^{* *}$ & $0.046^{* *}$ & $-0.617^{* *}$ & $0.683^{* *}$ \\
\hline DEBT & $0.113^{* *}$ & -0.006 & $0.208^{* *}$ & $0.393^{* *}$ & $0.063^{* *}$ & $-0.210^{* *}$ & 1.000 & $0.091^{* *}$ & $-0.027^{*}$ & $-0.036^{* *}$ & $0.058^{* *}$ & $-0.217^{* *}$ \\
\hline GC & $-0.028^{*}$ & -0.010 & $0.032^{* *}$ & $-0.059^{* *}$ & $-0.070^{* *}$ & $-0.073^{* *}$ & $0.091^{* *}$ & 1.000 & $-0.066^{* *}$ & -0.012 & $0.081^{* *}$ & $-0.044^{* *}$ \\
\hline BIGC & $0.085^{* *}$ & $-0.063^{* *}$ & $-0.571^{* *}$ & $0.081^{* * *}$ & $0.045^{* *}$ & $0.108^{* *}$ & $-0.027^{*}$ & $-0.066^{* *}$ & 1.000 & $0.068^{* *}$ & $-0.054^{* *}$ & $0.105^{* *}$ \\
\hline TENURE & $0.025^{*}$ & 0.017 & $-0.040^{* *}$ & $0.036^{* *}$ & 0.008 & $0.046^{* * *}$ & $-0.036^{* *}$ & -0.012 & $0.068^{* *}$ & 1.000 & $-0.049^{* *}$ & $0.033^{* *}$ \\
\hline LOSS & $-0.046^{* *}$ & 0.018 & -0.002 & $-0.186^{* *}$ & $-0.275^{* *}$ & $-0.617^{* *}$ & $0.058^{* *}$ & $0.081^{* * *}$ & $-0.054^{* *}$ & $-0.049^{* *}$ & 1.000 & $-0.383^{* *}$ \\
\hline OFC & -0.009 & -0.010 & $-0.038^{* *}$ & 0.014 & $0.143^{* *}$ & $0.683^{* *}$ & $-0.217^{* *}$ & $-0.044^{* *}$ & $0.105^{* *}$ & $0.033^{* *}$ & $-0.383^{* *}$ & 1.000 \\
\hline
\end{tabular}

\subsection{EMPIRICAL RESULTS}

Tables 4, 5, 6 and 7 are the empirical test results of each hypothesis in this study, including the overall model and the significance test of individual parameters. Table 4 explores the relationship between the power of the Top management teams and audit quality under the special variables of the control company. The empirical results show that the power of the company's top management teams (TMTPOWERi,t) and the audit quality proxy variable $\left(D A C_{i, t}\right)$ have a significant negative correlation. It is 0.043 , which is in line with the expectations of this study. It can be seen that the higher the power of the Top management teams of family firms, the higher the audit quality. According to the data from the 2017 Annual Meeting of the Taiwan Institute of Directors, based on the analysis of the total number of listed and OTC companies in Taiwan in 2016, 1,624, the market value of family businesses accounted for approximately $63 \%$ of the total market value of Taiwan, and the number of family entrepreneurs accounted for The total number of entrepreneurs is about $70 \%$, and the sample family companies in this study account for about $62.47 \%$, highlighting that most of the company's equity in
Taiwan is controlled by family members. The inference may be that the proportion of family businesses in Taiwan is relatively high, and family business CEOs tend to protect their own reputation, continue the business's sustainable operation, and pass it on to the next generation [7]. Therefore, the chief executive may avoid short-term opportunism such as earnings management and opaque financial reporting [20].

In terms of control variables, continuing operations doubters $\left(G C_{i, t}\right)$ and audit quality $\left(D A C_{i, t}\right)$ show a significant positive correlation, indicating that the more doubtful companies they continue to operate, the worse the audit quality; the CPA visa tenure $\left(T E N U R E_{i, t}\right)$ and audit quality $\left(D A C_{i, t}\right)$ indicate that The negative correlation is consistent with the findings of H Chung and S Kallapur [22], JR Francis and J Krishnan [32]; the current loss (LOSS) and audit quality $\left(D A C_{i, t}\right)$ show a significant positive correlation, indicating that the companies reporting losses in the current period will accrue more Project adjustment. The growth rate of sales $\left(G R O W_{i, t}\right)$ and audit quality $\left(D A C_{i, t}\right)$ show a significant positive correlation. The higher the sales growth in the current year, the more companies will adjust accruals the worse the audit quality. 
Table 4

Table 5 uses the CPA audit fee as the basis for the measurement of CPA independence $\left(A I_{i, t}\right)$, which is significantly positively correlated with audit quality $\left(D A C_{i, t}\right)$, indicating that when the importance of customers increases, the greater the degree of financial dependence of CPAs and the financial dependence on customers. The effect is greater than the effect of reputation maintenance. CPAs will allow clients to perform earnings management to retain specific clients. Therefore, the worse the CPA's independence, the audit quality will be affected [22]. It is consistent with the study of VD Sharma, DS Sharma and U Ananthanarayanan [34] that found that customers' and earnings management have a significant positive relationship with earnings adjustments, which generally supports Hypothesis 2.

Table 6 is based on the power of the top management team and the independence of CPAs, showing the regression results of the correlation between the two and audit quality $\left(D A C_{i, t}\right)$. The power of the top management team and CPA independence $\left(T M T P O W E R_{i, t} * A I_{i, t}\right)$ and audit quality $\left(D A C_{i, t}\right)$ has a significant negative correlation, supporting Hypothesis 3 , showing that the positive correlation between CPA independence $\left(A I_{i, t}\right)$ and audit quality $\left(D A C_{i, t}\right)$ is weakened by the power of the top management team. The inference is that the importance of customers is an important factor affecting the independence of CPAs. The greater the power of a company's top management team, the more it can affect the company's business model. When the CEO of a family business pays more attention to its reputation and its sustainability, management will attach importance to corporate governance and social responsibility fulfillment. The faithful expression of financial statements is the basic requirement of corporate governance. The high-level management team pays attention to the transparency and accuracy of the company's financial reports, affecting the audit quality of CPAs' checks.

\begin{tabular}{|c|c|c|}
\hline \multicolumn{3}{|c|}{ Empirical results of hypothesis H1 } \\
\hline Variables & Co-Efficient & P-Values \\
\hline Intercept & $-3.486^{* * *}$ & 0.000 \\
\hline TMTPOWER & $-0.043^{* * *}$ & 0.007 \\
\hline SIZE & $0.206^{* * *}$ & 0.000 \\
\hline GROW & $0.007^{* *}$ & 0.050 \\
\hline$R O A$ & $-0.002^{* * *}$ & 0.002 \\
\hline$D E B T$ & $-0.153^{* * *}$ & 0.000 \\
\hline$G C$ & $0.249^{* * *}$ & 0.000 \\
\hline$B I G C$ & 0.018 & 0.169 \\
\hline TENURE & $-0.005^{* *}$ & 0.033 \\
\hline LOSS & $0.037^{* * *}$ & 0.004 \\
\hline$O F C$ & 0.022 & 0.631 \\
\hline $\bar{N}$ & & 6,463 \\
\hline $\operatorname{Adj} R 2$ & & 0.404 \\
\hline F Value & & $119.297^{* * * *}$ \\
\hline \multicolumn{3}{|c|}{$\begin{array}{c}\text { Table } 5 \\
\text { Empirical results of hypothesis H2 }\end{array}$} \\
\hline Variables & Co-Efficient & P-Values \\
\hline Intercept & $-3.575^{* * *}$ & 0.000 \\
\hline$A I$ & $0.005^{* * *}$ & 0.000 \\
\hline SIZE & $0.206^{* * * *}$ & 0.000 \\
\hline GROW & $0.007^{* *}$ & 0.053 \\
\hline$R O A$ & $-0.002^{* * *}$ & 0.001 \\
\hline$D E B T$ & $-0.162^{* * * *}$ & 0.000 \\
\hline$G C$ & $0.240^{* * *}$ & 0.000 \\
\hline$B I G C$ & $0.080^{* * * *}$ & 0.000 \\
\hline TENURE & $-0.005^{* *}$ & 0.046 \\
\hline$L O S S$ & $0.037^{* * *}$ & 0.005 \\
\hline$O F C$ & 0.022 & 0.627 \\
\hline$N$ & & 6,463 \\
\hline Adj $R 2$ & & 0.405 \\
\hline F Value & & $119.805^{* * *}$ \\
\hline
\end{tabular}


Table 6

Empirical results of hypothesis $\mathrm{H} 3$

\begin{tabular}{llc}
\hline Variables & Co-Efficient & P-Values \\
\hline Intercept & $-3.539^{* * *}$ & 0.000 \\
TMTPOWER & -0.205 & 0.131 \\
AI & $0.008^{* * *}$ & 0.000 \\
TMTPOWER*AI & $-0.008^{* *}$ & 0.019 \\
SIZE & $0.205^{* * *}$ & 0.000 \\
GROW & $0.007^{*}$ & 0.056 \\
ROA & $-0.002^{* * *}$ & 0.002 \\
DEBT & $-0.156^{* * *}$ & 0.000 \\
GC & $0.230^{* * *}$ & 0.001 \\
BIGC & $0.069^{* * *}$ & 0.000 \\
TENURE & $-0.005^{*}$ & 0.051 \\
LOSS & $0.036^{* * *}$ & 0.006 \\
OFC & 0.024 & 0.603 \\
\hline$N$ & & 6,463 \\
Adj R2 & & 0.406 \\
F Value & & $114.119^{* * *}$ \\
\hline
\end{tabular}

\subsection{ADDITIONAL TEST}

Taiwan's high-tech electronics industry has excellent manufacturing technology, which is the lifeblood of Taiwan's economic development and plays an important role in the global high-tech industry. It currently accounts for about half of the number of listed companies in Taiwan. To understand the impact of high-tech industry top management team power $\left(T M T P O W E R_{i, t}\right)$ and the independence of certified CPA $\left(A I_{i, t}\right)$ on audit quality $\left(D A C_{i, t}\right)$, this study reexecutes Hypothesis 1, 2 and 3 tests on high-tech industry data, and presents the results table 7 . In Table 7. The analysis results found that the power of the top management team is negatively correlated with audit quality, and the independence of CPAs is positively correlated with audit quality, supporting Hypotheses 1 and 2 . In addition, the power of the TOP management team and CPA independence (TMTPOWER $\left.{ }_{i, t} * A I_{i, t}\right)$ and audit quality $\left(D A C_{i, t}\right)$ are negatively correlated, but the coefficient is small, which supports the hypothesis $\mathrm{H} 3$ of this study.
Table 7

Empirical results of the $h i g h$-tech industry additional test

\begin{tabular}{llc}
\hline Variables & Co-Efficient & P-Values \\
\hline INTERCEPT & $-3.509^{* * *}$ & 0.000 \\
TMTPOWER & $-0.028^{* *}$ & 0.098 \\
AI & $0.008^{* * *}$ & 0.000 \\
TMTPOWER ${ }^{*}$ AI & $-0.008^{* *}$ & 0.022 \\
SIZE & $0.205^{\text {****}}$ & 0.000 \\
GROW & $0.007^{* *}$ & 0.045 \\
ROA & $-0.002^{* * *}$ & 0.000 \\
DEBT & $-0.164^{* * *}$ & 0.000 \\
GC & $0.232^{* * *}$ & 0.000 \\
BIGC & $0.065^{* * *}$ & 0.001 \\
TENURE & $-0.005^{* *}$ & 0.037 \\
LOSS & $0.039^{* * *}$ & 0.003 \\
OFC & 0.058 & 0.201 \\
\hline$N$ & & 3,225 \\
Adj R2 & & 0.404 \\
F Value & & $113.470^{* * *}$ \\
\hline
\end{tabular}

\section{CONCLUSIONS AND RECOMMENDATIONS}

Financial statements help report users to make decisions and management in investment, credit, and taxation and are one of the major factors for stabilizing the operation of the capital market. The independence of CPAs is important to the credibility of financial statements and audit quality Impact. When the CPA's economic dependence on the client is higher, the CPA will try to reduce the possibility of deappointing the client. Therefore, the quality of the audit will be partially compromised. Taiwan's familyowned companies have a relatively high proportion. For the sake of their reputation and the sustainable operation of the company, the company's high-level management team must pass the success to the next generation smoothly. In addition to fulfilling its responsibilities to shareholders, it must also take care of consumers and consumers. Through the annual financial statements report, the social and environmental responsibilities of employees, creditors, suppliers, communities, and other stakeholders continue to communicate and convey the company's social responsibility. In addition, my country's 
financial management committee has gradually strengthened corporate governance and requirements for management teams in recent years, fearing that it will affect the decision of high-level management teams in the face of financial reporting and auditing quality.

This research integrates the top management teams' power theory, CPA economic independence theory, and reputation maintenance theory to explore the impact on audit quality. The empirical results show that as the TMT power of Taiwan companies increases, the audit quality is higher. It is different from the general research that the TMT will conduct earning management based on self-interested behavior. The inference is due to Taiwan's relatively high proportion of family companies. In the face of the trend of social responsibility and the requirements of regulatory agencies, the company's strategy of maintaining corporate image and successfully operating over to the next generation is presented with high audit quality. In addition, when CPAs face important clients, the CPA's economic dependence on important customers is greater than reputation maintenance, and the audit quality will be reduced. When the TMT power is greater, it will offset the CPA's economic dependence effect and enhance the audit quality.

The implementation process of this research strives to be objective and rigorous, but there are still the following limitations: First, the CPA's independence is evaluated based on the ratio of the client's public audit expenses to the public accounting firm's total public expenses. There are some measurement errors. Therefore, it is not appropriate to directly evaluate the abnormal accruals. The magnitude of the impact: This research only includes the data of listed companies in the TEJ database. Smaller companies cannot be included in this research, and no further analysis is made. This is also one of the limitations of this research. In terms of research topics that can be extended in the future, as the FSC's responsibility requirements for delinquent CPAs increase, changes will inevitably occur to the domestic CPA industry. When CPAs face increased practice risks, are they different in their audit and review decisions? If the top management team is led by professional managers, do they have different requirements for audit quality? These are very interesting questions, and future research can be further analyzed and discussed.

\section{ACKNOWLEDGMENT}

The authors wish to thank to the editor, the anonymous reviewers, and the participants of the virtual congress 2021 of the $43^{\text {rd }}$ European Accounting Association for their helpful comments. We acknowledge no external funding for this research work.

\section{REFERENCE}

1. Van Essen M, Otten J, Carberry EJ: Assessing managerial power theory: A meta-analytic approach to understanding the determinants of CEO compensation. Journal of management 2015, 41(1):164-202.

2. Muttakin MB, Khan A, Mihret DG: The effect of board capital and CEO power on corporate social responsibility disclosures. Journal of Business Ethics 2018, 150(1):41-56.

3. Gilson SC, Vetsuypens MR: CEO compensation in financially distressed firms: An empirical analysis. The Journal of Finance 1993, 48(2):425-458.

4. Farrell KA, Whidbee DA: Impact of firm performance expectations on CEO turnover and replacement decisions. Journal of Accounting and Economics 2003, 36(1-3):165196.

5. Demsetz $\mathrm{H}$ : The structure of ownership and the theory of the firm. The Journal of law and economics 1983, 26(2):375-390.

6. Demsetz $H$, Lehn $K$ : The structure of corporate ownership: Causes and consequences. Journal of political economy 1985, 93(6):1155-1177.

7. Anderson RC, Reeb DM: Founding-family ownership and firm performance: evidence from the S\&P 500. The journal of finance 2003, 58(3):1301-1328.

8. Choi JH, Kim JB, Liu X, Simunic DA: Audit pricing, legal liability regimes, and Big 4 premiums: Theory and cross-country 
evidence. Contemporary Accounting Research 2008, 25(1):55-99.

9. Egri $C P$, Herman S: Leadership in the North American environmental sector: Values, leadership styles, and contexts of environmental leaders and their organizations. Academy of Management journal 2000, 43(4):571-604.

10. Finkelstein S: Power in top management teams: Dimensions, measurement, and validation. Academy of Management journal 1992, 35(3):505-538.

11. Chemmanur TJ, Paeglis I: Management quality, certification, and initial public offerings. Journal of Financial Economics 2005, 76(2):331-368.

12. Ali $A$, Zhang $W$ : CEO tenure and earnings management. Journal of Accounting and Economics 2015, 59(1):60-79.

13. Alzoubi ESS: Audit quality and earnings management: evidence from Jordan. Journal of Applied Accounting Research 2016.

14. Fan JP, Wong TJ: Do external auditors perform a corporate governance role in emerging markets? Evidence from East Asia. Journal of accounting research 2005, 43(1):3572.

15. Lin Y-C, Lu Y-H, Lin F-C, Lu Y-C: Net Losses and the Relationship between Auditor Independence and Client Importance: Evidence from a Cubist Regression-Tree Model. Journal of Emerging Technologies in Accounting 2017, 14(1):13-25.

16. Hribar $\mathrm{P}$, Kravet $\mathrm{T}$, Wilson R: A new measure of accounting quality. Review of Accounting Studies 2014, 19(1):506-538.

17. DeFond ML, Francis JR: Audit research after sarbanes-oxley. Auditing: A journal of practice \& theory 2005, 24(s-1):5-30.

18. Kinney WR, Libby $R$ : The relation between auditors' fees for nonaudit services and earnings management: Discussion. The Accounting Review 2002, 77:107-114.

19. DeAngelo LE: Auditor size and audit quality. Journal of accounting and economics 1981, 3(3):183-199.
20. Prencipe A, Bar-Yosef S, Mazzola P, Pozza L: Income smoothing in family-controlled companies: Evidence from Italy. Corporate Governance: An International Review 2011, 19(6):529-546.

21. Ashbaugh $\mathrm{H}$, LaFond $\mathrm{R}$, Mayhew BW: Do nonaudit services compromise auditor independence? Further evidence. The accounting review 2003, 78(3):611-639.

22. Chung $H$, Kallapur $S$ : Client importance, nonaudit services, and abnormal accruals. The accounting review 2003, 78(4):931-955.

23. Frankel RM, Johnson MF, Nelson KK: The relation between auditors' fees for nonaudit services and earnings management. The accounting review 2002, 77(s-1):71-105.

24. Myers JN, Myers LA, Omer TC: Exploring the term of the auditor-client relationship and the quality of earnings: A case for mandatory auditor rotation? The accounting review 2003, 78(3):779-799.

25. Reynolds JK, Francis JR: Does size matter? The influence of large clients on office-level auditor reporting decisions. Journal of accounting and economics 2000, 30(3):375400.

26. Sweeney AP: Debt-covenant violations and managers' accounting responses. Journal of accounting and Economics 1994, 17(3):281308.

27. Dechow PM, Sloan RG, Sweeney AP: Detecting earnings management. Accounting review 1995:193-225.

28. ljaz A: AUDITOR INDEPENDENCE AND EARNINGS MANAGEMENT. 2019.

29. Becker $\mathrm{CL}$, DeFond $\mathrm{ML}$, Jiambalvo J, Subramanyam K: The effect of audit quality on earnings management. Contemporary accounting research 1998, 15(1):1-24.

30. DeFond $\mathrm{ML}$, Jiambalvo J: Debt covenant violation and manipulation of accruals. Journal of accounting and economics 1994, 17(1-2):145-176.

31. DeAngelo $H$, DeAngelo $L$, Skinner DJ: Accounting choice in troubled companies. 
Journal of accounting and economics 1994, 17(1-2):113-143.

32. Francis JR, Krishnan J: Accounting accruals and auditor reporting conservatism. Contemporary accounting research 1999, 16(1):135-165.

33. Chi W, Huang H: Discretionary accruals, auditfirm tenure and audit-partner tenure: Empirical evidence from Taiwan. Journal of Contemporary Accounting \& Economics 2005, 1(1):65-92.

34. Sharma VD, Sharma DS, Ananthanarayanan U: Client importance and earnings management: The moderating role of audit committees. Auditing: A Journal of Practice \& Theory 2011, 30(3):125-156. 